\title{
Evaluation of OSPE in FCPS Part II (Obs/Gynae) Examination Conducted by Bangladesh College of Physicians and Surgeons
}

\author{
Dr. Fahmida Zabin ${ }^{\prime}$, Prof. Soofia Khatoon ${ }^{2}$, Prof. Md. Humayun Kabir Talukder ${ }^{3}$
}

\begin{abstract}
Assessment plays a major role in the process of medical education. The clinical examination plays a key role in the assessment of students' competence to practice medicine. The conventional method of assessment does not include the assessment of clinical psychomotor skill, which students are learning throughout their clinical postings . The judgement of students performances is purely subjective and the same performance is graded differently by different examiners. A major advances in this area has been the formulation of an objective structured clinical/practical examination (OSCE/OSCE), which has been implemented successfully.

The objectives of this study were to evaluate OSPE in FCPS part II exam in Obs and Gynae conducted by Bangladesh College of Physicians and Surgeons (BCPS) in terms of exploration of quality of assessment tools as well as the opinion of the students and the examiners regarding OSPE.

A cross-sectional observational study was conducted among 150 students appearing in FCPS part II examination in Obs and Gynae of Bangladesh College of Physicians and Surgeons . Among the examiners 30 were included in the study. Study instrument consisted of two sets of self- administered questionnaires, one for the students and one for the examiners. Attitudes of students and examiners were collected by a grading scale (Likert scale). Different stations were analyzed by criteria of content coverage, skills assessed, clarity of languages, dominant domain assessed and time allocated for the task.
\end{abstract}

By analyzing the results of three sessions it shows that the percentage of pass varies from ten to fourteen percent. The overall opinion regarding OSPE shows that 54 percent of the students strongly agreed that this assessment system is a comprehensive one. About thirty seven percent and forty percent of students agreed on that it can assess wide range of knowledge and clinical competencies respectively .However student felt that clinical competencies respectively .However student felt that it was a strong anxiety producing experience. And concerns were expressed regarding the ambiguity of some questions and inadequacy of time for expected tasks in some stations. The majority of the students felt they were well oriented about the exam and that the required tasks were consistent with the actual curriculum that they were taught.

Ninety percent of examiners strongly agreed that it is a comprehensive system of assessment. Majority strongly agreed that it's a useful method of identifying gaps and weaknesses in competencies. About seventy percent agreed that checklists were well prepared. But forty percent had the opinion that there was some ambiguity of languages and ambiguity of instructions.

OSPE quality evaluation showed coverage of content was adequate. Most of the domain assessed was psychomotor domain.

In conclusion, both students and examiners agreed that the assessment was comprehensive and it was an objective and fair process. Overall opinions suggested that OSPE were restrictive, non discriminative and simplistic. The very nature of OSPE made it different from the traditional method. It was very much comprehensive and valid, covers a wide range of contents including practical skills.

\section{Introduction}

Assessment is a very important component of medical

${ }^{1}$ Associate Professor, Dept. of OB/GYN, Bangabandhu Sheikh

Mujib Medical University, Dhaka

${ }^{2}$ Professor, Dept. of Paediatrics, Shaheed Suhrawardy Medical College, Dhaka

${ }^{3}$ Professor, Curriculum Development \& Evaluation, Centre for Medical Education, Dhaka

Address of correspondence: Dr. Fahmida Zabin,

Associate Professor, Dept. of OB/GYN

Bangabandhu Sheikh Mujib Medical University, Dhaka

Cell: 01819228432, E-mail: fahmida.zabin@yahoo.com education,the efficacy of which is frequently in doubt. The existing examination system in majority of cases are dominated by the knowledge domain and in that, mere recall of facts, hardly any effort is made for assessing the psychomotor skills and no attention is paid for determining the attitudes( Harden,1979).The traditional clinical examination has been shown to have serious limitations in terms of its validity and reliability. The OSPE provides some answers to these limitations has become very popular. Many variants on the original OSCE format now exist and much research has been done on various aspect of their use. Issues to be addressed relate to organization matters and to the quality of the assessment. (Newble,1998).

Bangladesh Journal of Medical Education 2013;4(1):8-15. C 2013 Zabin et al., publisher and licensee Association for Medical Education. This is an Open Access article which permits unrestricted non-commercial use, provided the original work is properly cited. 
OSCE is a form of multi- station examination for clinical subjects first described by Harden et al from Dundee (1975). It was first reported from Dundee and Glasgow ( Harden and Gleeson, 1979).

OSCE is a form of multi- station examination for clinical subjects first described by Harden et al from Dundee (1975). It was first reported from Dundee and Glasgow ( Harden and Gleeson, 1979).

Competence is defined as what students should be able to do at an expected level of achievement. It may be regarded as the mastery of a body of relevant knowledge and acquisition of a range of relevant skills, which would include interpersonal, clinical and technical component. (Anshu, 2008).

The advent of the OSCE in the 1970s promised the equivalent advantages in clinical testing to that of objective written examinations in knowledge testing. In other words, the use of checklist based marking would enhance inter rater consistency and the testing of students' performance on multiple stations would increase the number and range of competencies that could be sampled. The OSCE has subsequently been subject to a considerable amount of research into its strengths and limitations, the outcomes of which form the basis of generalizations( Newble,1998).

The OSCE provides a test format particularly suitable for assessing many, but certainly not all, components of clinical competence. Overall, the OSCE is best suited to testing clinical, technical and practical skills and can do so across a very broad range, often with a high degree of fidelity. These include many skills that were never tested in the traditional clinical examination( Newble,1998).

Bangladesh College of Physicians and Surgeons are organizing the FCPS part- II examinations in different disciplines. Practical and clinical assessments are made by OSPE. All students first underwent written examination and those qualify the written test, gone through the OSPE examination as well as structured viva examination. There were twelve stations in OSPE circuit, two of them were rest stations .The different skills that should be assessed by OSPE were assessed in the remaining ten stations.

There was no study done yet to evaluate OSPE in any subjects in part-II FCPS examination conducted by BCPS. So this study will help for further improvement of OSPE by encouraging others to go for more studies regarding OSPE.

Through this study, we can get information about the present status of OSPE practiced in BCPS in FCPS part-II examination in Obs and Gynae. Results may be utilized later to improve the organization and conduction of OSPE. It will also give some input to the faculty, administrators and policy makers of medical education for future development of postgraduate medical education system.

\section{Materials and Method}

A cross-sectional observational study was carried out in Bangladesh College of Physicians and Surgeons from July
2007 to July 2008. The study included FCPS part- II (Obs/ Gynae) examinees and examiners appeared in sessions July 2007, January 2008 and July 2008.

The study included FCPS part- II (Obs/ Gynae) examinees and examiners appeared in sessions July 2007, January 2008 and July 2008 . 150 students who appeared in FCPS part-II examination were taken for the study.Among the examiners 30 were included in the study.Thirty OSPE stations were included in the study from three sessions.By convenient sampling, all the samples were taken. Research Instruments were- Self-administered structured questionnaires (with five point Likert scale) for teachers.Self-administered structured questionnaires (with five point Likert scale) for student.Self-administered semi structured questionnaires with open ended part both for teachers and students. The inclusion criteria is willingness to attend the study. Teachers: having an experience of being an examiner of FCPS part-II examination. Student: Who have appeared in of FCPS part-II examination.

A cross-sectional survey using a self-administered questionnaire were distributed among the students who have completed the OSPE circuits of that respective session. Students were asked to evaluate the content, structure and organization of the OSPE, rate the quality of performance and objectivity of the OSPE process, and also to give their opinion about the usefulness of the OSPE as an assessment instrument.

For Likert's scale score was given as-

5 means strongly agree, 4 means agree, 3 means not agreed

\begin{tabular}{|c|c|c|c|c|c|c|}
\hline SA & A & NAND & D & SD & Total & Mean \\
$($ Score & $($ Score & $($ Score & $($ Score & $($ Score & n $(\%)$ & Score \\
$5)$ & $4)$ & $3)$ & $2)$ & $1)$ & & $\&$ SD \\
\hline
\end{tabular}

and disagreed,2 means disagree and 1 means strongly disagree.

Questionnaire were coded manually and were undergone processed and analyzed by using SPSS computer software according to the objectives. For each variables, frequency distribution and mean score (mean of the scores of response) was calculated. Interpretation of mean score was as following-

1-2 = situation of the item areas were very bad and unacceptable, considerable effort is needed to improve the situation.

$>2-3=$ Situation of the item areas were bad and unacceptable, moderate effort is needed.

$>3-4=$ situation of the item areas were good, acceptable but some effort is needed to make it well acceptable.

$>4-5=$ situation of the item areas were very good, well acceptable and no need of further improvement.

Students were given voluntary choice to participate in the study. Teachers were also included in the study by voluntary choice. Confidentiality of the whole process was

Bangladesh Journal of Medical Education 2013;4(1):8-15. 
maintained. Ethical approval was taken from the authority of Bangladesh College of Physicians and Surgeons.

Data were collected and descriptive and non- parametric spplied using stata version 7. Basic statistical analysis of the Likert items was conducted by calculating frequencies, means and standard deviations. Qualitative analysis was Data done through a form of content analysis by identifying themes in student and teachers responses. Different stations were analysed .

\section{Results}

This cross sectional study was carried out in Bangladesh College of physicians \& Surgeons and the study population being, postgraduate FCPS part- II students appearing in the examination as well as the observers and assessors of the examination. Qualitative analysis was done through a form of content analysis by identifying the students' responses as well as teachers' responses

Table 1: Distribution of the respondents (Students) by their statements regarding organization of OSPE

\begin{tabular}{|l|c|c|c|c|c|c|c|}
\hline Statements & $\begin{array}{c}\text { SA } \\
\mathbf{( \% )}\end{array}$ & $\begin{array}{c}\text { SA } \\
(\mathbf{\%})\end{array}$ & $\begin{array}{c}\text { SA } \\
\mathbf{( \% )}\end{array}$ & $\begin{array}{c}\text { SA } \\
\mathbf{( \% )}\end{array}$ & $\begin{array}{c}\text { SA } \\
(\mathbf{\%})\end{array}$ & $\begin{array}{c}\text { SA } \\
\mathbf{( \% )}\end{array}$ & $\begin{array}{c}\text { SA } \\
\mathbf{( \% )}\end{array}$ \\
\hline Assessment by OSPE is a comprehensive one & 82 & $\begin{array}{c}29 \\
(54.7)\end{array}$ & $\begin{array}{c}8 \\
(19.3)\end{array}$ & $\begin{array}{c}05 \\
(5.3)\end{array}$ & $\begin{array}{c}26 \\
(3.3)\end{array}$ & $\begin{array}{c}150 \\
(17.3)\end{array}$ & $\begin{array}{c}4.34 \\
(100)\end{array}$ \\
\hline Wide range of knowledge were assessed by OSPE & 33 & 79 & 08 & 15 & 15 & 150 & 3.34 \\
\hline $\begin{array}{l}\text { Wide range of clinical competencies were assessed by } \\
\text { OSPE }\end{array}$ & $\begin{array}{c}69 \\
(46)\end{array}$ & $\begin{array}{c}37 \\
(24.7)\end{array}$ & $\begin{array}{c}10 \\
(6.6)\end{array}$ & $\begin{array}{c}19 \\
(12.7)\end{array}$ & $\begin{array}{c}15 \\
(10)\end{array}$ & $\begin{array}{c}150 \\
(100)\end{array}$ & $\begin{array}{c}3.94 \\
1.065\end{array}$ \\
\hline $\begin{array}{l}\text { Stations were arranged in organized and well sequenced } \\
\text { manner }\end{array}$ & 14 & 95 & 11 & 15 & 15 & 150 & 3.87 \\
\hline
\end{tabular}

$\mathrm{SA}=$ Strongly agree $, \mathrm{A}=\mathrm{Agree}, \mathrm{NAND}=$ Not agree not disagree, $\mathrm{D}=$ Disagree,

$\mathrm{SD}=$ Strongly disagree.

Table 1: Regarding organization of OSPE, fifty four percent of the students opined positively about comprehensiveness of OSPE and knowledge assessment (52\%), clinical competence (46\%). Sixty three percent students agreed that the stations were arranged in organized and well sequenced manner. Forty percent students strongly agreed that OSPE a is well organized assessment system. About twenty percent students strongly disagreed with the opinion.

Table 2: Distribution of the respondents (students) by their statements regarding conduction of OSPE

\begin{tabular}{|c|c|c|c|c|c|c|c|}
\hline Statements & $\begin{array}{l}\text { SA } \\
(\%)\end{array}$ & $\begin{array}{c}A \\
(\%)\end{array}$ & $\begin{array}{l}\text { NAND } \\
(\%)\end{array}$ & $\begin{array}{l}\text { D } \\
(\%)\end{array}$ & $\begin{array}{l}\text { SD } \\
(\%)\end{array}$ & $\begin{array}{l}\text { Total } \\
\text { n(\%) }\end{array}$ & $\begin{array}{l}\text { Mean } \\
\text { \& SD }\end{array}$ \\
\hline Time allowed for procedure station was adequate & $\begin{array}{c}23 \\
(15.3)\end{array}$ & $\begin{array}{c}84 \\
(56)\end{array}$ & $\begin{array}{c}8 \\
(5.3)\end{array}$ & $\begin{array}{c}19 \\
(12.7)\end{array}$ & $\begin{array}{c}16 \\
(10.7)\end{array}$ & $\begin{array}{l}150 \\
(100)\end{array}$ & $\begin{array}{c}3.42 \\
1.243\end{array}$ \\
\hline Tasks were consistent with the curriculum & $\begin{array}{c}60 \\
(40)\end{array}$ & $\begin{array}{c}64 \\
(42.7)\end{array}$ & $\begin{array}{c}11 \\
(7.3)\end{array}$ & $\begin{array}{c}7 \\
(4.7)\end{array}$ & $\begin{array}{c}8 \\
(5.3)\end{array}$ & $\begin{array}{c}150 \\
(100)\end{array}$ & $\begin{array}{l}3.60 \\
1.231\end{array}$ \\
\hline $\begin{array}{l}\text { Stressfulness of the examination as compared to } \\
\text { traditional system were less }\end{array}$ & $\begin{array}{c}70 \\
(46.7)\end{array}$ & $\begin{array}{c}26 \\
(17.3)\end{array}$ & $\begin{array}{c}8 \\
(5.3)\end{array}$ & $\begin{array}{c}19 \\
(14)\end{array}$ & $\begin{array}{c}16 \\
(10.7)\end{array}$ & $\begin{array}{c}150 \\
(100)\end{array}$ & $\begin{array}{c}2.45 \\
1.067\end{array}$ \\
\hline Observers graded with fairness & $\begin{array}{c}79 \\
(52.7)\end{array}$ & $\begin{array}{c}26 \\
(17.3)\end{array}$ & $\begin{array}{c}2 \\
(1.3)\end{array}$ & $\begin{array}{c}23 \\
(15.3)\end{array}$ & $\begin{array}{c}20 \\
(13.3)\end{array}$ & $\begin{array}{c}150 \\
(100)\end{array}$ & $\begin{array}{c}3.58 \\
1.154\end{array}$ \\
\hline $\begin{array}{l}\text { OSPE provided a satisfactory environment for } \\
\text { examination }\end{array}$ & $\begin{array}{l}11 \\
(7.3)\end{array}$ & $\begin{array}{l}106 \\
(70.7)\end{array}$ & $\begin{array}{c}2 \\
(1.3)\end{array}$ & $\begin{array}{c}10 \\
(6.7)\end{array}$ & $\begin{array}{c}21 \\
(14.0)\end{array}$ & $\begin{array}{c}150 \\
(100)\end{array}$ & $\begin{array}{c}3.90 \\
1.034\end{array}$ \\
\hline Topics selected in OSPE helped for better learning & $\begin{array}{c}55 \\
(11.4)\end{array}$ & $\begin{array}{c}259 \\
(53.5)\end{array}$ & $\begin{array}{c}86 \\
(17.8)\end{array}$ & $\begin{array}{c}60 \\
(12.4)\end{array}$ & $\begin{array}{l}24 \\
(5)\end{array}$ & $\begin{array}{c}484 \\
(100)\end{array}$ & $\begin{array}{c}3.54 \\
1.033\end{array}$ \\
\hline Chance of Examiners' biasness were less & $\begin{array}{c}107 \\
(71.3)\end{array}$ & $\begin{array}{c}22 \\
(14.7)\end{array}$ & $\begin{array}{c}6 \\
(04)\end{array}$ & $\begin{array}{c}7 \\
(4.7)\end{array}$ & $\begin{array}{c}8 \\
(5.3)\end{array}$ & $\begin{array}{c}150 \\
(100)\end{array}$ & $\begin{array}{l}4.17 \\
1.013\end{array}$ \\
\hline $\begin{array}{l}\text { No chance of showing negative attitude of examiners } \\
\text { towards examinees }\end{array}$ & $\begin{array}{c}100 \\
(66.7)\end{array}$ & $\begin{array}{c}28 \\
(18.7)\end{array}$ & $\begin{array}{c}7 \\
(4.7)\end{array}$ & $\begin{array}{c}3 \\
(02)\end{array}$ & $\begin{array}{c}12 \\
(08)\end{array}$ & $\begin{array}{c}150 \\
(100)\end{array}$ & $\begin{array}{c}3.99 \\
1.164\end{array}$ \\
\hline
\end{tabular}

Bangladesh Journal of Medical Education 2013;4(1):8-15. 
Table 2: Most of the students agreed that alloted time for procedure station $(56 \%)$ was adequate. However, positive opinion were found on fairness of grading $(52 \%), \&$ better learning (53\%). Almost $70 \%$ gave opinion that OSPE provided a satisfactory environment in examination and less chance of showing negative attitude towards examinees $(66 \%)$..

Table 3: Frequency distribution of suggestions given by the students for improvement of present practice of OSPE

\begin{tabular}{|l|c|}
\hline Suggestions & Frequency \\
\hline $\begin{array}{l}\text { Long procedure stations should be } \\
\text { avoided }\end{array}$ & 30 \\
\hline Easier procedure stations should be included & 25 \\
\hline More analytical questions can be given & 8 \\
\hline $\begin{array}{l}\text { Number of procedure stations should be } \\
\text { increased }\end{array}$ & 27 \\
\hline $\begin{array}{l}\text { Answers of question stations should not be } \\
\text { too large }\end{array}$ & 31 \\
\hline Proper sitting arrangement should be done & 28 \\
\hline $\begin{array}{l}\text { Instructions should be clearly } \\
\text { understandable }\end{array}$ & 10 \\
\hline Teachers should be more cooperative & 20 \\
\hline $\begin{array}{l}\text { More skilled teachers are required } \\
\text { practice of OSPE }\end{array}$ & 36 \\
\hline $\begin{array}{l}\text { During classes, teachers should discuss } \\
\text { OSPE of the related chapters }\end{array}$ & 12 \\
\hline $\begin{array}{l}\text { During course teachers can help to improve } \\
\text { (a) }\end{array}$ & 36 \\
\hline
\end{tabular}

Table 3 shows suggestions given by the student. Open ended questions were supplied to the examinees for some suggestions regarding OSPE. One hundred and thirteen students responded to the open-ended questions. There were multiple responses. There were responses which showed that avoidance of long procedure stations, more number of procedure stations, provision for practice of OSPE and proper sitting arrangement were most frequent suggestions.

\section{Teachers' Responses}

Table 4: Distribution of the respondents (teachers) by their statements regarding organization of OSPE

\begin{tabular}{|c|c|c|c|c|c|c|c|}
\hline Statements & $\begin{array}{l}\text { SA } \\
(\%)\end{array}$ & $\begin{array}{c}\text { A } \\
(\%)\end{array}$ & $\begin{array}{c}\text { NAND } \\
(\%)\end{array}$ & $\begin{array}{c}\text { D } \\
(\%)\end{array}$ & $\begin{array}{l}\text { SD } \\
(\%)\end{array}$ & $\begin{array}{l}\text { Total } \\
\text { n(\%) }\end{array}$ & $\begin{array}{l}\text { Mean } \\
\text { \& SD }\end{array}$ \\
\hline Coverage of content in OSPE were satisfactory & - & $\begin{array}{c}13 \\
(43.29)\end{array}$ & $\begin{array}{c}7 \\
(23.3)\end{array}$ & $\begin{array}{c}10 \\
(33.3)\end{array}$ & - & $\begin{array}{c}30 \\
(100)\end{array}$ & $\begin{array}{l}3.71 \\
.953\end{array}$ \\
\hline Most of the topics are of high difficulty level & $\begin{array}{c}2 \\
(3.33)\end{array}$ & - & $\begin{array}{c}7 \\
(23.32) \\
\end{array}$ & $\begin{array}{c}6 \\
(19.98) \\
\end{array}$ & $\begin{array}{c}15 \\
(50)\end{array}$ & $\begin{array}{c}30 \\
(100)\end{array}$ & $\begin{array}{l}1.98 \\
.965 \\
\end{array}$ \\
\hline Assessment by OSPE is a comprehensive one & $\begin{array}{c}9 \\
(29.97)\end{array}$ & $\begin{array}{c}15 \\
(50)\end{array}$ & $\begin{array}{c}3 \\
(10)\end{array}$ & $\begin{array}{c}3 \\
(10)\end{array}$ & & $\begin{array}{c}30 \\
(100)\end{array}$ & $\begin{array}{c}4.29 \\
1.535\end{array}$ \\
\hline Checklists used in OSPE were well prepared & $\begin{array}{c}3 \\
(10)\end{array}$ & $\begin{array}{c}18 \\
(59.94)\end{array}$ & - & $\begin{array}{c}6 \\
(19.98)\end{array}$ & $\begin{array}{c}3 \\
(10)\end{array}$ & $\begin{array}{c}30 \\
(100)\end{array}$ & $\begin{array}{r}3.60 \\
.978 \\
\end{array}$ \\
\hline $\begin{array}{l}\text { Language used for station construction are clearly } \\
\text { understandable }\end{array}$ & - & $\begin{array}{c}11 \\
(36.7)\end{array}$ & $\begin{array}{c}7 \\
(23.3)\end{array}$ & $\begin{array}{c}12 \\
(40)\end{array}$ & - & $\begin{array}{c}30 \\
(100)\end{array}$ & $\begin{array}{l}3.74 \\
.988\end{array}$ \\
\hline
\end{tabular}

Bangladesh Journal of Medical Education 2013;4(1):8-15. 
Table 4 shows the opinion of the teachers regarding organization of OSPE. $43.29 \%$ of the teachers opined positively about core content coverage but there was disagreement on clarity of language (40\%). 50\% of the teachers felt that most of the topics were not of high difficulty level.

Table 5: Distribution of the respondents (teachers)by their statements regarding organization of OSPE (having issues only with teachers' activity)

\begin{tabular}{|l|c|c|c|c|c|c|c|}
\hline Statements & $\begin{array}{c}\text { SA } \\
\mathbf{( \% )}\end{array}$ & $\begin{array}{c}\mathbf{A} \\
\mathbf{( \% )}\end{array}$ & $\begin{array}{c}\mathbf{N A N D} \\
\mathbf{( \% )}\end{array}$ & $\begin{array}{c}\mathbf{D} \\
\mathbf{( \% )}\end{array}$ & $\begin{array}{c}\text { SD } \\
\mathbf{( \% )}\end{array}$ & $\begin{array}{c}\text { Total } \\
\mathbf{n}(\mathbf{\%})\end{array}$ & $\begin{array}{c}\text { Mean } \\
\text { \& SD }\end{array}$ \\
\hline $\begin{array}{l}\text { Topics selected in OSPE bears relevance with real life } \\
\text { situation }\end{array}$ & $\begin{array}{c}3 \\
(9.99)\end{array}$ & $\begin{array}{c}24 \\
(79.92)\end{array}$ & - & 2 & 1 & 30 & 3.23 \\
$(6.66)$ & $(3.33)$ & $(100)$ & .845 \\
\hline Advance planning is done by the examiners & 3 & 20 & 4 & 3 & - & 30 & 3.52 \\
& $(9.99)$ & $(66.6)$ & $(13.32)$ & $(9.99)$ & & $(100)$ & 1.056 \\
\hline Organization of OSPE is checked by examiners & 9 & 18 & - & 3 & - & 30 & 3.73 \\
& $(29.97)$ & $(59.94)$ & & $(9.99)$ & & $(100)$ & 1.031 \\
\hline Construction of stations are prepared well ahead & 11 & 15 & - & 4 & - & 30 & 3.50 \\
& $(36.63)$ & $(49.95)$ & & $(13.32)$ & & $(100)$ & 1.074 \\
\hline Check lists are prepared well ahead & 8 & 16 & - & 6 & - & 30 & 3.50 \\
& $(26.64)$ & $(53.28)$ & & $(19.98)$ & & $(100)$ & 1.065 \\
\hline $\begin{array}{l}\text { Check lists are prepared by group of teachers in } \\
\text { consensus way }\end{array}$ & 19 & 8 & - & 3 & - & 30 & 3.50 \\
$(19.27)$ & $(26.64)$ & & $(9.99)$ & & $(100)$ & 1.048 \\
\hline
\end{tabular}

Table 5 shows that positive responses were available from teachers regarding advance planning $(66 \%)$, checking by examiners $(59 \%)$, and well ahead construction of station
(63\%), well ahead construction of check list (53\%). Seventy percent agreed on relevance of OSPE with real life situation and preparation of check list by group of teachers( $63 \%)$..

Table 6: Distribution of the respondents (teachers) by their statements regarding their perception about organization of OSPE

\begin{tabular}{|l|c|c|c|c|c|c|c|}
\hline Statements & $\begin{array}{c}\text { SA } \\
(\%)\end{array}$ & $\begin{array}{c}\mathbf{A} \\
\mathbf{( \% )}\end{array}$ & $\begin{array}{c}\text { NAND } \\
\mathbf{( \% )}\end{array}$ & $\begin{array}{c}\mathbf{D} \\
\mathbf{( \% )}\end{array}$ & $\begin{array}{c}\text { SD } \\
\mathbf{( \% )}\end{array}$ & $\begin{array}{c}\text { Total } \\
\mathbf{n}(\mathbf{\%})\end{array}$ & $\begin{array}{c}\text { Mean } \\
\text { \& SD }\end{array}$ \\
\hline $\begin{array}{l}\text { Marks allocated in different stations are proportional to } \\
\text { the tasks }\end{array}$ & $\begin{array}{c}5 \\
(16.65)\end{array}$ & $\begin{array}{c}14 \\
(46.62)\end{array}$ & $\begin{array}{c}3 \\
(9.99)\end{array}$ & $\begin{array}{c}5 \\
(16.65)\end{array}$ & $\begin{array}{c}3 \\
(9.99)\end{array}$ & $\begin{array}{c}30 \\
(100)\end{array}$ & 3.63 \\
.984 \\
\hline $\begin{array}{l}\text { OSPE helps in getting more marks than Traditional } \\
\text { Practical Exam }\end{array}$ & $\begin{array}{c}8 \\
(26.64)\end{array}$ & $\begin{array}{c}22 \\
(73.26)\end{array}$ & - & - & - & 30 & 4.40 \\
\hline Topics selected in OSPE helped for better learning & 6 & 16 & - & 7 & 1 & 30 & 3.86 \\
& $(19.98)$ & $(53.28)$ & & $(23.31)$ & $(3.33)$ & $(100)$ & .983 \\
\hline Construction of stations are difficult & 1 & 20 & 4 & 5 & - & 30 & 2.58 \\
& $(3.33)$ & $(66.6)$ & $(13.32)$ & $(16.65)$ & & $(100)$ & .962 \\
\hline Construction of stations are time consuming & 20 & 6 & 2 & 2 & - & 30 & 3.28 \\
& $(66.6)$ & $(19.98)$ & $(6.66)$ & $(6.66)$ & & $(100)$ & .962 \\
\hline $\begin{array}{l}\text { Through OSPE all three domains-knowledge, skill \& } \\
\text { attitude can be assessed }\end{array}$ & 14 & 9 & - & 7 & - & 30 & 3.64 \\
\hline
\end{tabular}

Table 6 shows teachers responses about their perception on OSPE. Most of the teachers agreed with the proposition that OSPE helps students in getting more marks than traditional practical exam. $66 \%$ teachers did not feel that construction of station is difficult. Most of the teachers opined positively for other propositions.

Bangladesh Journal of Medical Education 2013;4(1):8-15. 
Table 7: Frequency distribution of suggestions given by teachers for improvement of present practice of OSPE

\begin{tabular}{|l|c|}
\hline \multicolumn{1}{|c|}{ Suggestions } & Frequency \\
\hline Standard question bank should be formulated & 4 \\
\hline $\begin{array}{l}\text { Total number of OSPE stations should be } \\
\text { increased }\end{array}$ & 4 \\
\hline $\begin{array}{l}\text { Stations should be of } 10 \text { minutes duration to } \\
\text { complete the whole task }\end{array}$ & 2 \\
\hline $\begin{array}{l}\text { More emphasis should be given for } \\
\text { understanding and applied level of cognitive } \\
\text { domain }\end{array}$ & 2 \\
\hline Skilled teachers should be involved in OSPE & 15 \\
\hline $\begin{array}{l}\text { OSPE stations should be prepared by a central } \\
\text { expert body }\end{array}$ & 8 \\
\hline $\begin{array}{l}\text { More teachers should be trained in constructing } \\
\text { OSPE stations }\end{array}$ & 12 \\
\hline
\end{tabular}

Table 7 shows different suggestions given by the teachers about OSPE. Twenty five teachers responded and most frequent suggestions was skilled teachers should be involved in this procedure. Another suggestion was that teachers should be trained in constructing OSPE stations.

Table 8: Analysis of different stations of OSPE of three sessions by different criteria

Table 8 shows analysis of the stations of three sessions by means of different criteria. The content coverage was adequate in different stations according to the curriculum of FCPS part-II. In question answer stations as well as in procedural stations, the instructions given were well understood. Time allocation for different tasks to be done were also adequate. The domain which was most frequently assessed was cognitive domain.

\begin{tabular}{|l|l|l|l|}
\hline Criteria & July 2007 & January 2008 & July 2008 \\
\hline Content coverage & Adequate & Adequate & Adequate \\
\hline Skills assessed & $\begin{array}{l}\text { Uniform combination of } \\
\text { different skills }\end{array}$ & More procedural skills & $\begin{array}{l}\text { Uniform combination of } \\
\text { different skills }\end{array}$ \\
\hline Clarity of languages & Well understood & Well understood & Well understood \\
\hline Preparation of checklist & Well prepared & Well prepared & Well prepared \\
\hline Time allocation for each task & Adequate & Adequate & Adequate \\
\hline Dominant domain & Cognitive & Psychomotor & Cognitive \\
\hline
\end{tabular}

\section{Discussion}

This study was a cross sectional observational study to evaluate the OSPE conducted by BCPS for part-II FCPS in OBGYN. Evaluation was done in regards to opinion of students and examiners. Different stations were analyzed according to different criteria such as content coverage, skill assessed, clarity of languages in different instructions, check list preparation, dominant domain assessed and adequacy of time for each station.

\section{Organization of OSPE having issues common for students and teachers:}

Organization of OSPE has many aspects to consider. Out of those we considered 5 (five) variables which were common to both students and teachers.

Comprehensive way of assessment: This study revealed that $75 \%$ of students and fifty one percent of teachers thought that assessment by OSPE is a comprehensive one (Table $2 \&$ Table 5). In this study both teachers and students agreed on the point about the present practice of OSPE is a comprehensive one.
Clarity of language: About seventy three percent students agreed that language used for OSPE stations were clearly understandable and unambiguous (Table-4). But 40\% teachers had agreement and disagreement respectively on the point (Table-6). Although Shankar (2002) observed that medium of instruction can play some role in performance which may be wrongly interpreted as absence of clarity. In our study population the bulk of the students came from Bangla medium in their pre medical studies.

Difficulty level: It was found that $70 \%$ of teachers thought that most of the topics were not of high difficulty level (Table-6). Difficulty level of a question should be mixed one, where some of the questions should be of high difficulty level and some should be reasonably easy to complete/perform (Gitanjali, 1999).

\section{Various issues of students' and teachers' during conduction of OSPE:}

Time for procedure station: Seventy one point three percent of student felt that time allowed for procedure station was adequate (Table-3). A study by Gitanjali (1999) 
showed that less time will only test a student how fast they can do the test rather how well they could perform it. Pakhale (2012) found that $60.8 \%$ students needed more time at each station. But in present study $63.27 \%$ teachers thought that time allocation for a station was adequate (Table-9).

Fairness by observer: Seventy percent of students agreed on the observers' fairness on grading (Table-3). Eighty percent of students agreed on fairness of assessment with Duffield \& Spencer (2002). Construction of stations: About $86.58 \%$ teachers gave opinion that construction of stations were done well ahead but at the same time agreed that it's construction was time consuming. $69.93 \%$ teacher gave opinion that construction of stations were difficult (Table8). Gitanjali (2004) found that this was really time consuming, and difficult to maintain uniform difficulty level of the stations.

III. Various issues of OSPE regarding preparation for conduction

Question bank formation: About $86.58 \%$ teachers said that after the examination the stations were used for question bank formation (Table-10). In fact a large question bank would put some positive impact for future examinations. Bijlani (2004) also emphasized for formulating question bank.

Test evaluation: In present study $56.58 \%$ teachers gave opinion that test evaluation was not done properly (Table10). Singleton et al (1999) have showed an effective way of evaluating OSCE stations, and they concluded that evaluation indicates OSCE as a valuable formative assessment.

Adequacy of teacher and staff: Only $52 \%$ teachers felt that adequate staffs were present in the college (Table-10). BCPS had a large number of Fellows in OBS and GYNAE who were engaged in OSPE for smooth conduction of this event.

\section{Factors identified by students in attending OSPE}

Instruments and materials used in OSPE: About $68.6 \%$ of students gave opinion ,that the Dummys which were used in OSPE were handled by the students easily(table-4). About $74.7 \%$ students also opined positively that the simulators took part in the communication skill stations were well trained (Table-4). Usually simulators were the recently passed young doctors who did not even took part in FCPS part-I examination.

Stress in OSPE: In present study 64\% students gave opinion that stress of OSPE compared to traditional examination were less (Table-3). In fact the students usually had a number of mock tests before examination.

\section{Problems identified by teachers in conducting OSPE}

About $50 \%$ of the respondents found problem in conducting
OSPE(Table-11). Out of those problems three most common problems were discussed below (Table-11).

Inadequate observer/examiner: This was the most frequently identified problem identified by the teachers. As large number of students appeared in FCPS part-II examination in OBS and GYNAE, it took whole day to conduct OSPE ( running six circuits at a time). So a huge number of observers and assessors were required. This problem should be addressed properly for smooth conduction of OSPE.

Sometimes there is problem with the answer key: Some of the teachers identified problems with the answer key. Hasan et al (2009) also observed similar situation and to overcome this they suggested for participation of all faculty members in preparing check list and conduction of OSPE. In an editorial, Chan (2011) emphasized that OSCE (OSPE) stations should be designed by team work. It increases the validity.

\section{References}

Abraham, RR, Upadhya,S, Tokre, S and Ramnarayan, K (2005). Student perspective of assessment by TEMM model in Physiology. Advan. Physiol. Edu. 29: 94-97.

Allen R, Heard J, Savidge M, Bittengle J, Cantrell M, Huffmaster T(1998). Surveying student's attitudes during the OSCE. Adv Health Sci Educ, No 3: 197-206.

Alistair MS Chesser.(2004). Factor analysis can be a useful setting tool in a high stakes OSCE assessment. Medical Education: $38(8): 825-831$.

Al-Mously, N, Nabil, MN, Salem, R, 2012, Student feedback on OSPE: an experience of a new medical school in Saudi Arabia, J Int Assoc of Med Sc Educators; 22 (1): 1016.

Begum, T (2005). Objective Structured Clinical Examination(OSCE)- An Approach in Assessment of Clinical Competence. Journal of Surgical Sciences. Vol9(2): 58-61, Black, P, William (1998). Inside the black box. Phi Delta Kappan,80 (2),139-148.

David, A, Sloan, Michae, 1B. Donnelly, Richard, Schwartz and William, E, Strodel (1995). The Objective Structured Clinical Examination. The New Gold Standard for Evaluating Postgraduate Clinical Performance. ANNALS OF SURGERY Vol.222,No. 6, 735-742.

Duffield, KE, Spencer, JA (2002). A survey of medical students' views about the purposes and fairness of assessment. Med Educ (36): 879-886.

Duerson, MC, Romrell, LJ, Stevens, CB (2008). Impacting faculty teaching and student performance: nine years experience with the objective structured clinical examination. Teach Learn Med, 12: 76-182. PubMed Abstract.

Bangladesh Journal of Medical Education 2013;4(1):8-15. 
Faculty of Medical Sciences, University of the West Indies, Mona In Report- MB, BS undergraduate Compiled responses from FAIMER fellows and faculty (2008). Introduction and basics of OSPE/OSCE.

Programme, (2011/12) First Annual Report on Curriculum Development. FMS, UWI.Mona, Jamaica. Fraimertraining 2008-01.page 1-4. https://sites.google.com/site/ faimertraining $2008 /$ basicsofospeosce.

Friedman, B, David, M, 2000, The role of assessment in expanding professional horizonMedTeach,22:472-77.

Gourlund, N, E, Measurement \& Evaluation of Teaching. Macmillan. New York 6th edition. 1976.590

Guskey, T, R (2000). Grading policies that work against standards and how to fix them. NASSP Bulletins, 84 (620), 20-29.

Gitanjali, B, 2004, The other side of OSPE, Indian J Pharmacol, 36:388-9.

Harden,RM and Gleeson, FA (1979). ASME Education Booklet No 8. Assessment of Clinical Competence using an Objective Structured Clinical Examination (OSCE).pp 210.

Harden, RM, Cairncross, RG (1980). Assessment of practical skills: The Objective Structured Clinical Examination(OSPE). Studies in Higher Education, Vol 5,Issue 2, 187-196.

Harden, RM, Epstein, MD(2007). Assessment in Medical Education. N England Journal Med 356: 386- 396.

Hasan, S, Malik, S, Hamad, A, Khan, H, Bilal, M, 2009, Coventional/traditional practical examination(CPE/TDPE) versus Objective structured practical examination (OSPE)/ semi objective structured practical evaluation (SOSPE), Pak J Physio, 5(1): 58-64.

Kenneth, OC (2007) The last Frontier.Trackling the grading dilemma. Ahead of the curve : The power of assessment to transform Teaching \& Learning. Ch 6, $1^{\text {st }}$ ed. Solution tree (Booklet 2) P 127-145.

Knox, JDE (1976). Association for the study of Medical Education. The modified Essay question Booklet No 5. Edinburgh, Scotland 25 pages.

Kowlowitz, V, Hoole, AJ, Sloane, PD(1991): Implementation of the Objective Structured Clinical Examination in a traditional medical school. Acad Med, 66(6): 345-347. PubMed Abstract.

Lennox, B. (1974). Hints on the setting and evaluation of MCQ of the one from the five type. ASME Medical education booklet 3. ASME Dundee.28 pages.

Menon,MA, Jouglin, GR, Menon, B (1999). Oral assessment \& Postgraduate examination: establishing conditions for validity, reliability \& fairness. Adv Health
Sci Educ Theory Pract. 15(2): 277-89.

Marzano, RJ (2006). Classroom assessment \& grading that work. Alexandria: ASCD. website www.ascd.org/write.

Newble, DI and Swanson, DB (1988). Psychometric characteristics of the objective structured clinical examination. Med Educ . 22: 325-334. Newble, DI(1988). Eight years experience with a structured clinical examination. Med Educ . No 22: 200-204. PubMed Abstract.

Pakhale, SV, Mahajan, AA, Fating, AS, Ghule, SB, Borole, BS, 2012, Study of student's perception regarding increasing objectivity during practical examination in anatomy, International journal of health sciences \& research; 2 (4): 48-53.

Pierre, RB, Wierenga, A, Barton, M, Thame, K, Branday, JM, Christie, CDC (2005).Student Self-assessment in a Paediatric Objective Structured Clinical Examination. West Indian Medical J 54(2):144.

Qureshi, GS, Parveen, S, Yasmeen, T,( 2012), Objective structured practical examination (OSPE): an experience at Dow university of health sciences (DUHS) Karachi, Medical channel; 18(1):5-8.

Rick, W (2007). Fair isn't always equal: Assessing \& grading in the differentiated classroom. Portland, ME: Sten house Publisher (3) pp 120-121.

R, Douglus (2004). Putting it all together: Standards, Assessment and Accountability. Acountability for learning: How Teachers \& School leaders can take charge. P 106-113.

Shankar, RP and Mishra, P (2002), Student feedback on the objective structured component of the practical examination in pharmacology, Clinical medicine \& health research (net print).

Shumway, JM, Harden, RM (2003). AMEE Guide No 25. The assessment of learning outcome for the Competent \& reflective physician. Med Teach. Nov; 25 (6): 569-584.

Stokes, JF (1974). The clinical examination assessment of clinical skills. ASME Medical Education Booklet No 2. ASME. Dundee. 22 pages.

Stiggins, R (2007). Assessment for learning: An essential foundation of productive instruction. Ahead of the curve. The power of assessment to transform Teaching \& Learning. P 59-76.

Woodburn, J, Sutcliffe: The reliability, validity and evaluation of the objective structured clinical examination in podiatry. Assessment Evaluation Higher Educ, 21: 131147.

Wilson, M and Sloane, K. From principles to Practice: An Embedded Assessment System. Graduate School of Education University, Berkeley, CA. Applied Measurement in Education, 13(2). 181-208. 